\title{
Estradiol and its membrane-impermeable conjugate estradiol-BSA inhibit tamoxifen-stimulated prolactin secretion in incubated rat pituitaries
}

\author{
R Aguilar, C Bellido, J C Garrido-Gracia, R Alonso ${ }^{1}$ and J E Sánchez-Criado \\ Department of Cellular Biology, Physiology and Immunology, University of Córdoba Avda, Menendez Pidal s/n, \\ 14004 Córdoba, Spain and ${ }^{1}$ Department of Physiology, University of La Laguna, Spain
}

Correspondence should be addressed to J E Sánchez-Criado; Email: fi1sacrj@uco.es

\begin{abstract}
In the absence of estrogen (E), the selective E receptor modulator tamoxifen (TX) has two agonist effects in the rat pituitary: induction of progesterone receptor (PR)-dependent GnRH self-priming in the gonadotrope, and stimulation of prolactin (PRL) secretion in the lactotrope. TX-induced gonadotropin $(\mathrm{GnRH})$ self-priming is absent when $10^{-8} \mathrm{M}$ estradiol-17 $\beta$ ( $\left.\mathrm{E}_{2}\right)$ is added to the incubation medium of pituitaries from TX-treated rats. The present experiments investigated whether PR-independent $P R L$ release into the incubation medium of pituitaries from TX-treated ovariectomized (OVX) rats was affected by $E_{2}$, and the effect of different ER ligands (ICI182780, TX, estradiol-17 $\left.\alpha, E_{2}-B S A\right)$ on TX-stimulated PRL secretion. Moreover, the effect of $E_{2}$ on TRH-stimulated PRL secretion in pituitaries collected from estradiol benzoate- and TX-treated OVX rats was studied. It was found that: i) incubation with $E_{2}$ supressed the PRL releasing effect of injected TX; ii) whereas coincubation with the pure anti-E type II ICI182780 antagonized the inhibitory effect of $E_{2}$, coincubation with the anti-E type I TX did not; iii) estradiol$17 \alpha$ lacked inhibitory action, whereas a dose-dependent inhibitory effect of both $E_{2}$ and $E_{2}-B S A$ was noticed; and iv) TRH stimulatory effect on PRL release in pituitaries from TX-treated rats was blocked by addition of $E_{2}$ to the medium. Taken together, these data argue in favor of the presence of specific membrane recognition sites for $E$ in the lactotrope involved in steroid-specific $E_{2}$ inhibition of TX-stimulated PRL secretion.

Reproduction (2006) 131 763-769
\end{abstract}

\section{Introduction}

In the rat, secretion of prolactin (PRL) plays a critical role in the maintenance of corpus luteum progesterone secretion during the first half of pregnancy (Morishige \& Rothchild 1974, Gibori 1993), mammary tissue through lactation (Tucker 1988), and promoting structural luteolysis in nonfunctioning corpora lutea (Rothchild 1981, Sánchez-Criado et al. 1987). In addition to neurogenic stimuli arising from the environment, estrogen $(\mathrm{E})$ is considered to be the most potent endogenous stimulator of PRL secretion (Neill 1988, Pelletier et al. 2003). Classically, E acts by binding to its nuclear receptors in pituitary lactotropes that, in turn, interact with specific DNA sequences to modulate their expression (Watters et al. 2000). Ovariectomy and neutralization of circulating $E$ levels with an antiserum reduce PRL secretion (Neill et al. 1971, Neill 1972), and administration of anti-E to E-treated ovariectomized (OVX) rats decreases circulating levels of PRL (Gotze et al. 1984, Spritzer et al. 1996).
Tamoxifen (TX) is a selective estrogen receptor modulator (SERM) that has tissue-selective agonist properties in the rat. TX displays agonist activity at vaginal level, while reducing E action on uterus weight (González et al. 2000). At pituitary level, TX displays mixed agonist/antagonist activities. Whereas in the presence of the cognate ligand, TX antagonizes E action on luteinizing hormone (LH) (Tebar et al. 1994, Sánchez-Criado et al. 2002) and PRL (Lieberman et al. 1983, Spritzer et al. 1996) secretion, in the absence of the cognate ligand, TX induces GnRH selfpriming without affecting basal or GnRH-stimulated $\mathrm{LH}$ release in incubated pituitaries (Sánchez-Criado et al. 2002), and stimulates PRL secretion (González et al. 2000, Bellido et al. 2003). Incubated pituitaries from two-week OVX rats injected daily over three days with $3 \mathrm{mg}$ TX exhibit increased PRL release into the medium, as do pituitaries from OVX rats injected with the cognate ligand (Bellido et al. 2003). In this model, TX has been found to induce progesterone receptor (PR) expression in gonadotropes (Bellido et al. 2003, Sánchez-Criado et al. 2004). Activation of these PR by $\mathrm{GnRH}$-increased intracellular 
cAMP levels, in a P-independent manner (Waring \& Turgeon 1992, Turgeon \& Waring 1994), elicits GnRH selfpriming (Bellido et al. 2003). This agonistic effect of TX is silenced by the addition of $10^{-8} \mathrm{M}$ estradiol- $17 \beta\left(\mathrm{E}_{2}\right)$ or the membrane-impermeable conjugate $E_{2}-B S A$ to the medium, suggesting the mediation of a surface $E$ receptor (ER) (Bellido et al. 2005). Because GnRH self-priming is a unique response among endocrine cells (Fink 1995), which involves CAMP-PKA signaling pathway cross-talk with the PR (Waring \& Turgeon 1992, Turgeon \& Waring 1994), it may be that the inhibitory action of $E_{2}$ on TX-induced $\mathrm{GnRH}$ self-priming is also an unequaled response of gonadotropes. TX stimulates PRL secretion most probably through nuclear ER $\alpha$ (Sánchez-Criado et al. 2004, 2005); lactotropes do not express PR (Fox et al. 1990, SánchezCriado et al. 2005) and CAMP is the intracellular mediator for PRL secretion (Neill 1988). For these reasons, the aims of the present study were: first, to determine whether $E_{2}$ added to the incubation medium of pituitaries from TXtreated rats suppressed TX-stimulated PRL secretion, and secondly to search for the possible site and mode of action of this paradoxical $E_{2}$ effect on lactotropes.

\section{Materials and Methods}

\section{Animals and surgery}

Adult female Wistar rats weighing $200 \pm 15 \mathrm{~g}$ were used. Rats were housed under a $14 \mathrm{~h}$ light: $10 \mathrm{~h}$ darkness cycle (lights on at 05:00 h) at room temperature $\left(22 \pm 2{ }^{\circ} \mathrm{C}\right)$ with ad libitum access to rat chow and tap water. All rats were OVX under ether anesthesia at random stages of the estrous cycle and included in experiments two weeks later. All experimental protocols were approved by the Ethical Committee of the University of Córdoba, and experiments were performed in accordance with the rules on laboratory animal care and international law on animal experimentation.

\section{Treatments}

In the first experiment, three groups of 12 OVX rats each were daily injected s.c. at $0900 \mathrm{~h}$ over three days either with $0.2 \mathrm{ml}$ oil, $25 \mu \mathrm{g}$ estradiol benzoate (EB; Sigma) or $3 \mathrm{mg}$ of the SERM TX (Sigma). In the second experiment, 48 OVX rats all injected with TX were used. Finally, in the third experiment, three groups of OVX rats treated as in the first experiment were employed. At $0900 \mathrm{~h}$ on the first day after treatment, rats from all three experiments were decapitated, the neural lobe discarded and anterior pituitary glands dissected out, divided in halves, and incubated. Doses employed of EB and TX came from previous publications by this laboratory (Bellido et al. 2003, 2005, Sánchez-Criado et al. 2002, 2004, 2005).

\section{General incubation procedure}

Incubation of pituitaries was carried out as previously described (Bellido et al. 2003, Sánchez-Criado et al. 2004).
Briefly, halves of anterior pituitaries were incubated for $180 \mathrm{~min}$, after $60 \mathrm{~min}$ preincubation, at $37^{\circ} \mathrm{C}$ with constant shaking (60 cycles/min) in an atmosphere of $95 \%$ $\mathrm{O}_{2} / 5 \% \quad \mathrm{CO}_{2}$. Each incubation tube contained $1 \mathrm{ml}$ of Dulbecco's modified Eagle's medium (DMEM), without L-glutamine and phenol red, containing glucose $(4.5 \mathrm{~g} / \mathrm{l})$ and bovine serum albumin (BSA, $0.1 \%, w / v), p H 7.4$. All medium was aspirated every 60 min for quantification of PRL concentrations by specific RIA and replaced with fresh medium containing the corresponding test substance.

\section{Incubation experiments}

In the first experiment, 24 hemipituitaries from each of the three groups (oil-, EB- and TX-injected OVX rats) were randomly allocated, in groups of eight, to one of the following three incubation conditions: medium alone, $10^{-8} \mathrm{M} 17 \beta$ estradiol $\left(E_{2}\right)$ (Sigma) and $10^{-7}$ M TX. The nine groups of hemipituitaries were otherwise submitted to the same incubation protocol. In the second experiment, 96 hemipituitaries from TX-injected rats were randomly allocated $(n=8$ hemipituitaries/treatment group) to one of the following incubation conditions: medium alone, $10^{-7} \mathrm{M} \mathrm{TX} ; 10^{-7} \mathrm{M}$ ICI182780, a pure anti-E (Tocris Cookson Ltd, Avonmouth, UK); or with: $10^{-10}, 10^{-8}, 10^{-6} \mathrm{M} \mathrm{E}_{2}, 10^{-8} \mathrm{M}$ of the stereoisomer $17 \alpha E_{2}$ (Sigma); $10^{-10}, 10^{-8}, 10^{-6} M E_{2}-B S A$ (Sigma). In addition, pituitaries from TX-treated rats incubated with $10^{-8} \mathrm{M} \mathrm{E}_{2}$ were coincubated with $10^{-7} \mathrm{M}$ ICI182780 or $10^{-7} \mathrm{M}$ TX. In the final experiment, 16 hemipituitaries from 8 oil-treated rats incubated with medium alone, 16 hemipituitaries from 8 EB-injected rats wereincubated with $10^{-8} \mathrm{M} \mathrm{E}_{2}$, and 32 hemipituitaries from 16 TX-treated rats incubated either with $10^{-7} \mathrm{M}$ TX (16 hemipituitaries) or $10^{-8} \mathrm{M} \mathrm{E}_{2}$ (16 hemipituitaries) were co-incubated with $10^{-8} \mathrm{M}$ TRH $(n=8$ hemipituitaries/treatment group) or without $10^{-8} \mathrm{M} \mathrm{TRH}(n=8$ hemipituitaries/ treatment group).

\section{Pituitary weight and protein content determination}

Additional OVX rats injected over three days either with $0.2 \mathrm{ml}$ oil, $25 \mu \mathrm{g}$ EB or $3 \mathrm{mg}$ TX (4 rats/group) were decapitated on the first day after treatments. Their anterior pituitary glands were dissected out, weighed, divided in halves, and processed for protein content following the procedure previously described using bicinchoninic acid (Smith et al. 1985).

\section{RIA of PRL}

Concentrations of PRL in incubation media were measured in duplicate, by specific RIA, using a doubleantibody method with a kit supplied by NIH (Bethesda, MD, USA), and a previously described microassay method (Sánchez-Criado et al. 2004). Intra- and inter-assay coefficients of variation were $8 \%$ and $9 \%$, respectively, and assay sensitivity was $10 \mathrm{pg} /$ tube. Each PRL value (ng/hemipituitary) was divided by the mean of the corresponding 
pituitary protein content and expressed either as $\mathrm{ng} / \mathrm{mg}$ protein of the reference preparation PRL-rat-RP3, or in arbitrary units, as the area under the curve (AUC) calculated by the trapezoidal rule.

\section{Statistical analysis}

PRL data were presented as mean + S.E.M. of eight hemipituitaries/group. Statistical analysis was performed by ANOVA followed by Student-Newman-Keuls multiple range test for comparison among means. Significance was considered at the 0.05 level.

\section{Results}

Treatment with EB increased $(P<0.05)$ pituitary weight and pituitary protein content: $15.55 \pm 0.93 \mathrm{mg}$ and $0.68 \pm 0.04 \mathrm{mg} /$ hemipituitary, respectively, in comparision to oil-injected rats: $10.23 \pm 0.47 \mathrm{mg}$ and $0.48 \pm$ $0.02 \mathrm{mg} /$ hemipituitary. Treatment with TX had no effect: $11.00 \pm 0.66 \mathrm{mg}$ and $0.49 \pm 0.02 \mathrm{mg} /$ hemipituitary.

Regardless of incubation conditions (medium alone, $\mathrm{E}_{2}$ or TX) pituitaries from OVX rats injected with EB or TX, but not those from OVX rats injected with oil, displayed in vitro, increased PRL secretion (Fig. 1). The stimulating effect of E on PRL release was higher $(P<0.05)$ than that of TX (Fig. 1). Overall, incubation conditions did not influence PRL release into the medium, except when $E_{2}$ was added to the medium of pituitaries from TX-treated rats. In this case, PRL released into the incubation medium decreased, to such an extent that it did not differ from PRL secretion of pituitaries from oil-injected rats (Fig. 1). The inhibitory effect of $E_{2}$ on TX-stimulated PRL secretion was

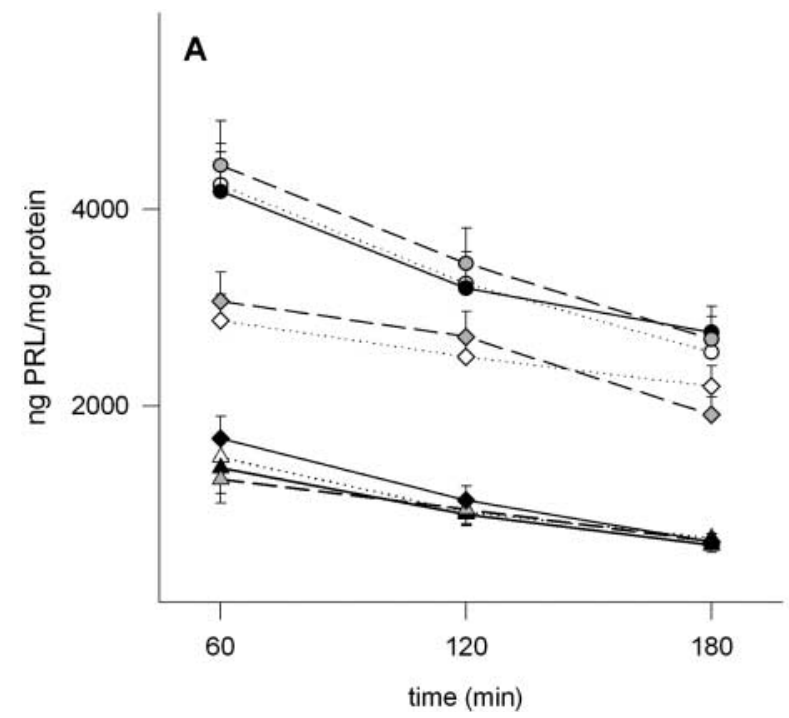

reversed by coincubation with the anti-E ICI182780, but not by TX, while in the absence of $E_{2}$ in the incubation medium, ICI182780 or TX alone had no effect on TX-stimulated PRL secretion (Fig. 2). In contrast to the lack of inhibitory effect of the stereoisomer estradiol-17 $\alpha$ on PRL release (Fig. 2), both the cognate ligand $E_{2}$ and its membraneimpermeable conjugate $\mathrm{E}_{2}-\mathrm{BSA}$ inhibited, in a dosedependent manner, PRL secretion of pituitaries from TXtreated rats (Fig. 2). Moreover, addition of TRH to the medium stimulated PRL secretion in pituitaries from oil-, EBand TX-treated rats when incubated with the corresponding test substances: medium alone, $\mathrm{E}_{2}$ or $\mathrm{TX}$, respectively. However, TRH had no stimulatory activity on PRL release in pituitaries from TX-treated rats incubated with $E_{2}$ (Fig. 3).

\section{Discussion}

Regardless of incubation conditions, data from the present study showed that in vivo treatments (oil, EB or TX) determined the in vitro pituitary PRL secretory pattern. Thus, addition of $E_{2}$ or TX to the medium did not affect PRL release in pituitaries from rats injected either with oil, EB or TX. This was true except when $E_{2}$ was added to the incubation medium of pituitaries collected from TX-treated rats, which resulted in complete inhibition of the TX stimulating effect on PRL release. This negative effect of $E_{2}$ was strictly dependent on the in vivo treatment, since addition of $E_{2}$ to the medium of pituitaries from oil- or EBtreated rats had no effect on PRL secretion. The lack of $E_{2}$ effect on PRL secretion in pituitaries from oil- or EBinjected OVX rats may be due to $E$ withdrawal in the former (Sánchez-Criado et al. 2005) and the occupancy of the complete ER orchestra in the latter.

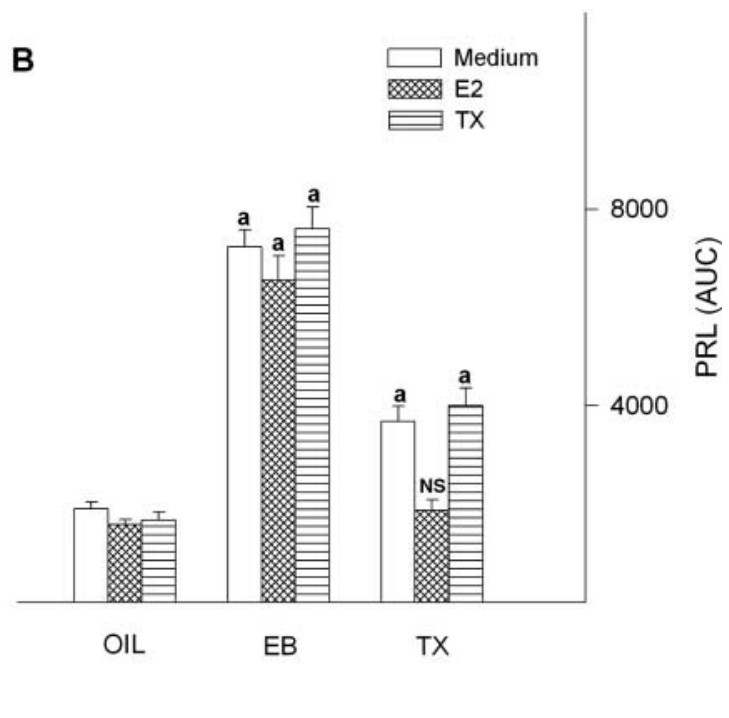

Figure 1 (A) PRL release (ng/mg protein) into incubation medium of pituitaries from two-week OVX rats injected daily over three days with $0.2 \mathrm{ml}$ oil (triangles), $25 \mu \mathrm{g}$ estradiol benzoate (EB, circles) or $3 \mathrm{mg}$ tamoxifen (TX, diamonds) and incubated for three hours with: medium alone (white), $10^{-8} \mathrm{M}$ estradiol-17 $\beta$ ( $E_{2}$, black) or $10^{-7} \mathrm{M} \mathrm{TX}$ (grey). (B) PRL secretion expressed as area under the curve (AUC) in arbitrary units in the nine experimental groups of the first experiment is represented in B. Values are mean + S.E.M. $(n=8$ hemipituitaries). a, $P<0.05$ vs. oil-injected rats; NS, not significant vs. oil-injected rats (ANOVA and Student-Newman-Keuls multiple range test). 


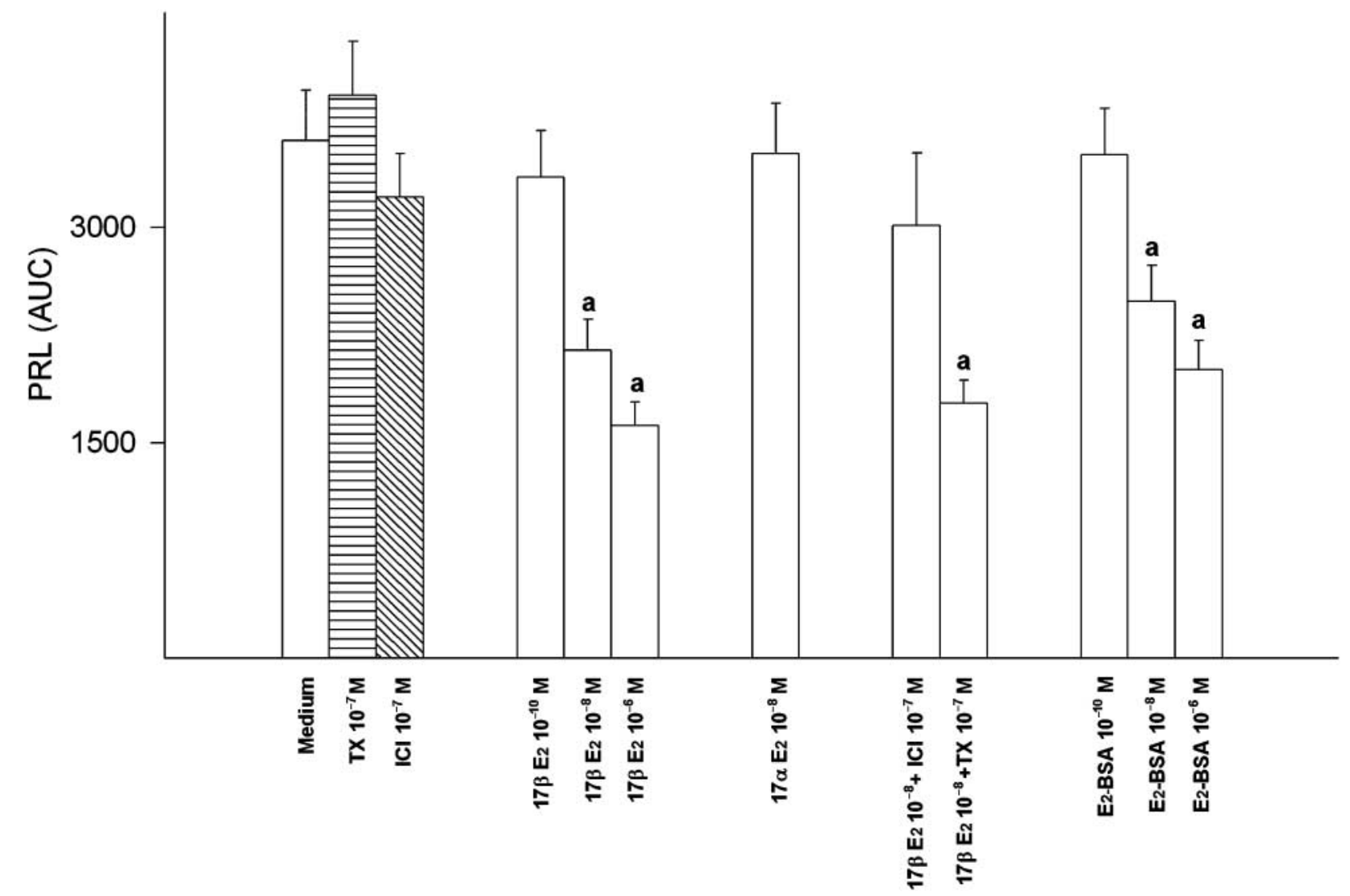

Figure 2 PRL release into incubation medium of pituitaries from two-week OVX rats injected daily over three days with $3 \mathrm{mg}$ TX and incubated for three hours with: medium alone, $10^{-7} \mathrm{M} \mathrm{TX} ; 10^{-7} \mathrm{M} \mathrm{ICl} 182780(\mathrm{ICl}) ; 10^{-10}, 10^{-8}, 10^{-6} \mathrm{M}_{\text {of }} \mathrm{E}_{2} ; 10^{-8} \mathrm{M} 17 \alpha$-estradiol; $10^{-8} \mathrm{M} \mathrm{E}_{2}+10^{-7} \mathrm{M}$ $\mathrm{ICl} ; 10^{-8} \mathrm{M} \mathrm{E}_{2}+10^{-7} \mathrm{M} \mathrm{TX}$; and $10^{-10}, 10^{-8}, 10^{-6} \mathrm{M} \mathrm{E}_{2}-\mathrm{BSA}$. PRL secretion is expressed as area under the curve (AUC) in arbitrary units. 8 hemipituitaries/group. a, $P<0.05$ vs. controls: medium alone, TX and ICI. (ANOVA and Student-Newman-Keuls multiple range test).

The finding that the agonistic action of the antagonist TX on PRL secretion was antagonized by the cognate agonist is intriguing, as is the fact that physiological concentrations of $E_{2}$ in the incubation medium for less than two hours were able to inhibit the stimulatory action on PRL secretion of a three-day pharmacological treatment of TX bound to nuclear ER (Sánchez-Criado et al. 2004, 2005). Moreover, the present data indicated that the $\mathrm{E}_{2}$ blockade of the agonist effect of TX on PRL secretion was reversed by ICI182780, a pure anti-E type II (Smith \& O'Malley 2004) that competitively blocks E binding to all known ER (Leondires et al. 1999, McEwen \& Alves 1999, Navarro et al. 2003, Perez-Martin et al. 2003), but not by the antiE type I TX (Smith \& O'Malley 2004). Thus, $E_{2}$ appeared to inhibit the agonistic effect of TX on lactotropes acting on ER exhibiting both high affinity for the anti-E ICI182780 and extremely low affinity for TX. For these reasons, it seems that this previously undescribed inhibitory action of $E_{2}$ on PRL release could be exerted at a non-classical ER in the lactotrope. It has been shown that lactotrope expresses $E R \alpha$ and $\beta$ isoforms (Mitchner et al. 1998, 1999), and probably surface ER $\alpha$ (Christian \& Morris 2002, Bulayeva et al. 2005). It has also been demonstrated that $E_{2}$ binds pituitary membranes with high affinity, and that 4-OH-TX, which is 100 -fold more potent than TX as an anti-E (Jordan et al. 1988), does not displace $\mathrm{E}_{2}$ binding to rat pituitary membranes (Bression et al. 1986). In contrast, the membrane ER- $\alpha$-mediated rapid stimulation of PRL release in a pituitary cell line is blocked by ICl182780 (Bulayeva et al. 2005). As reported previously for other SERM (Hardy \& Valverde 1994, McDonnell 2003), the use of TX in the present experiments may have revealed a novel action of $\mathrm{E}$ on rat lactotropes.

In addition to its well defined actions in the nucleus (Watters et al. 2000), E has rapid regulatory effects on several membrane associated responses not dependent on changes in gene expression in reproductive tissues (Pietras \& Szego 1977). In various cell types, including pituitary cells, there is increasing evidence for non-genomic E effects (Schmidt et al. 2000, Kelly \& Levin 2001) which, through occupancy of the cell surface ER, triggers membrane associated cytoplasmic signaling cascades that affect cell function (Bression et al. 1986). In the present study, incubation of pituitaries from TX-treated rats with increasing concentrations of the analog membraneimpermeable conjugated $\mathrm{E}_{2}-\mathrm{BSA}$, which prevent the steroid from entering the cell (Bression et al. 1986), significantly decreased PRL secretion in a dose-dependent 


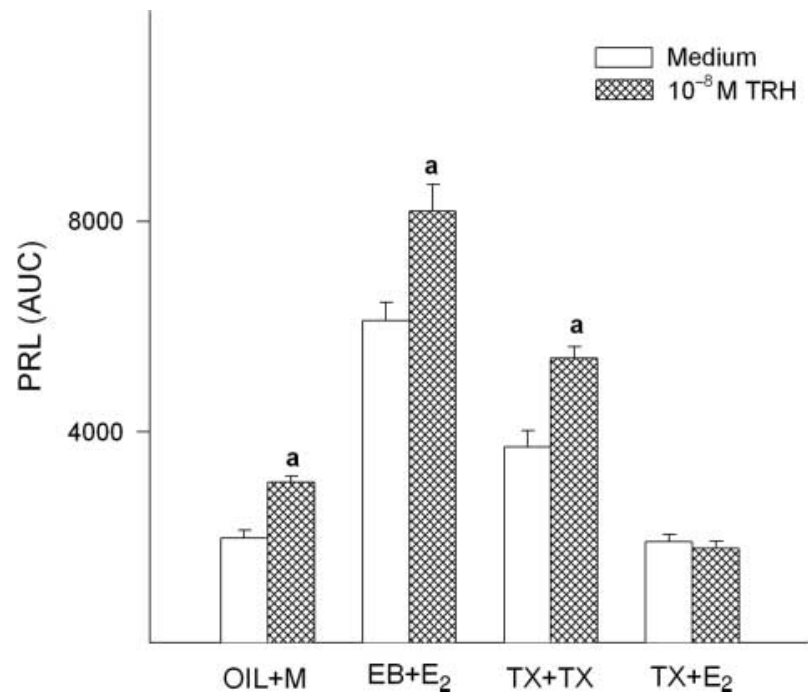

Figure 3 Effect of $10^{-8} \mathrm{M}$ TRH on PRL release into incubation medium of pituitaries from two-week OVX rat injected daily over three days with $0.2 \mathrm{ml}$ oil, $25 \mu \mathrm{g}$ EB or $3 \mathrm{mg}$ TX and incubated for three hours with: medium alone $(\mathrm{M}), 10^{-8} \mathrm{M} \mathrm{E}_{2}$ and $10^{-7} \mathrm{MTX}$, respectively. Pituitaries from TX-treated OVX rats incubated with $E_{2}\left(T X+E_{2}\right)$ were also included. PRL release is expressed as AUC in arbitrary units. 8 hemipituitaries/group. a, $P<0.05$ vs. non-stimulated controls (ANOVA and Student-Newman-Keuls multiple range test).

manner, as did $E_{2}$. It is to be noted that $E_{2}$ inhibition of TX-stimulated PRL secretion was evidenced in DMEM containing $0.1 \%$ BSA. Since $10^{-8} \mathrm{M}$ of the $\mathrm{E}_{2}$ stereoisomer estradiol- $17 \alpha$ had no inhibitory effect on PRL secretion in TX-treated rats, it seems that the steroid specific $E_{2}$ inhibition of TX-stimulated PRL secretion is through specific membrane recognition sites for $E$ in the lactotrope with extremely low affinity for TX.

Pituitary PRL release is strictly dependent on $E$ background (Neill 1988, Mitchner et al. 1999). $E_{2}$ exerts its excitatory in vivo effect on PRL release by enhancing TRH stimulatory effects and suppressing inhibitory influences of dopamine (Neill 1988), respectively. The primary mechanism of $E_{2}, T R H$ and dopamine actions in the lactotrope involves CAMP as a second messenger (Dannies et al. 1976, Barnes et al. 1978, Brozmanova et al. 1980, Snyder et al. 1981, Gautvik et al. 1982, Neill 1988). Present data also showed that: (i) addition of TRH to the incubation medium effectively stimulated PRL release in pituitaries regardless of whether it was primed with $\mathrm{E}$ or TX, and (ii) that incubation with $E_{2}$ annulled the stimulatory effect of the secretagogue TRH in TX-treated rats. There are several lines of evidence suggesting that $E_{2}$ inhibition of TX-induced PRL secretion may involve a cAMP/PKA signaling pathway. First, cAMP induces E-like effects in reproductive tissues involving $G$ proteins and second messenger systems in several aspects of E action (Aronica et al. 1994, Katzenellenbogen 1996, Yoshioka et al. 1999) and TX induces cAMP production in rat pituitary cells (Guelmes et al. 2005). Secondly, whereas a stimulatory effect of nanomolar concentrations of $E$ for $60 \mathrm{~min}$ was detected in hypothalamic neurons, an inhibitory effect of physiological picomolar $\mathrm{E}_{2}$ levels exerted on membrane associated receptors in cAMP signaling and $\mathrm{GnRH}$ secretion has been demonstrated in hypothalamic neurons (Navarro et al. 2003). Such inhibitory responses are abolished by the ER antagonist ICI182780 and mimicked by $\mathrm{E}_{2}$-BSA (Navarro et al. 2003). Thirdly, incubation of pituitaries from TX-treated rats with $E_{2}$ inhibits $\mathrm{GnRH}$ self-priming but not $\mathrm{GnRH}$-stimulated $\mathrm{LH}$ release (Bellido et al. 2005). Unlike the GnRH-releasing action of LH, which involves $\mathrm{Ca}^{2+}$ and PKC (Stojilkovic et al. 1994), GnRH self-priming is a protein-synthesis dependent phenomenon (Fink 1995), that is dependent on cAMP cross-talk with PR in a ligand-independent manner (Waring \& Turgeon 1992, Turgeon \& Waring 1994).

Taking into account that CAMP is the intracellular mediator for PRL secretion (Neill 1988) and that lactotropes do not express PR (Fox et al. 1990, Sánchez-Criado et al. 2005), we are now tempted to speculate that the putative ER membrane-mediated inhibitory effect of $E_{2}$ on TX-stimulated PRL secretion could be part of a general mechanism of inhibition of CAMP production and/or action. The possible existence in the lactotrope of nuclear and plasma membrane ER, which might prompt cross-talk between intracellular and extracellular effects of $E$ (Blaustein 2004) is suggestive of the existence of a modulatory role in lactotrope function capable of exquisite finetuning of E action.

\section{Acknowledgements}

This work was subsidized by grants (BFI2002-00485 and BFU2005-01443) from DGI-MCYT, Spain. The authors thank the National Hormone and Pituitary Program (Baltimore, MD, USA) for the PRL RIA kit. The technical assistance of Teresa Recio is appreciated. The authors declare that there is no conflict of interest that would prejudice the impartiality of this scientific work.

\section{References}

Aronica SM, Kraus WL \& Katzenellenbogen BS 1994 Estrogen action via the CAMP signaling pathway: stimulation of adenylate cyclase and cAMP-regulated gene transcription. PNAS 91 8517-8521.

Barnes GD, Brown BL, Gard TG, Atkinson D \& Ekins RP 1978 Effect of TRH and dopamine on cyclic AMP levels in enriched mammotroph and thyroytoph cells. Molecular and Cellular Endocrinology 12 273-284.

Bellido C, Martín de las Mulas J, Tena-Sempere M, Aguilar R, Alonso R \& Sánchez-Criado JE 2003 Tamoxifen induces gonadotropin-releasing hormone self-priming through an estrogen-dependent progesterone receptor espression in the gonadotrope of the rat. Neuroendocrinology 77 425-435.

Bellido C, Aguilar R, Alonso R, Garrido-Gracia JC \& Sánchez-Criado JE 2005 Estradiol-17 $\beta$ blocks the estrogenic effect of tamoxifen on $\mathrm{LH}$ and PRL secretion in he rat. Journal of Physiology and Biochemistry 61 149-150.

Blaustein JD 2004 Minireview: Neuronal steroid hormone receptors: they're not just for hormones anymore. Endocrinology 145 $1075-1081$. 
Bression D, Richard M, Le Dafniet M, Pagesy P \& Peillon F 1986 Evidence for a specific estradiol binding site on rat pituitary membranes. Endocrinology 119 1048-1051.

Brozmanova H, Langer P, Foldes O, Kolena J \& Knopp J 1980 In vitro effect of TRH on adenylate cyclase and cAMP in rat anterior pituitary and on TSH and PRL release into incubation medium. Endocrinologia Experimentalis 14 291-296.

Bulayeva NN, Wozniak AL, Lash LL \& Watson CS 2005 Mechanism of membrane estrogen receptor- $\alpha$-mediated rapid stimulation of $\mathrm{Ca}^{2+}$ levels and prolactin release in a pituitary cell line. American Journal of Physiology. Endocrinology and Metabolism 288 E388-E397.

Christian HC \& Morris JF 2002 Rapid actions of $17 \beta$-oestradiol on a subset of lactotrophs in the rat pituitary. Journal of Physiology 539 557-566.

Dannies PS, Gautvik KM \& Tashjian AH Jr 1976 A possible role of cyclic AMP in mediating the effects of thyrotropin-releasing hormone on prolactin release and on prolactin and growth hormone synthesis in pituitary cells in culture. Endocrinology 98 1147-1159.

Fink G 1995 The self-priming effect of LHRH: a unique servomechanism and possible cellular model for memory. Frontiers in Neuroendocrinology 16 183-190.

Fox SR, Harlan RE, Shivers BD \& Pfaff DW 1990 Chemical characterization of neuroendocrine targets for progesterone in the female rat brain and pituitary. Neuroendocrinology 51 276-283.

Gautvik KM, Kriz M, Jahnsen T, Haug E \& Hansson V 1982 Relationship between stimulated prolactin release from GH cells and cyclic AMP degradation and formation. Molecular and Cellular Endocrinology 26 295-308.

Gibori G 1993 The corpus luteum of pregnancy. In The ovary, pp 261-317. Eds EY Adashi \& PCK Leung. New York: Raven Press.

González D, Bellido C, Aguilar R, Garrido-Gracia JC, Herrnández G, Alonso R \& Sánchez-Criado JE 2000 Luteinizing hormone secretion elicited in a ligand-independent activation of progesterone receptor manner at pituitary level in the rat: differential effect of two selective estrogen receptor modulators. Neuroscience Letters 289 111-114.

Gotze S, Nishino Y \& Neumann F 1984 Anti-oestrogenic effects of tamoxifen on mammary gland and hypophysis in female rats. Acta Endocrinologica 105 360-370.

Guelmes P, Abreu G, Hernández G, Sánchez-Criado JE \& Alonso R 2005 Effects of estradiol and tamoxifen on adenylyl cyclase (AC) system in anterior pituitary cells. Journal of Physiology and Biochemistry 61 151-152.

Hardy SP \& Valverde MA 1994 Novel plasma membrane action of estrogen and antiestrogens revealed by their regulation of a large conductance chloride channel. FASEB Journal 8 760-765.

Jordan VC, Koch R, Langan S \& McCague R 1988 Ligand interaction at the estrogen receptor to program antiestrogen action: a study with nonsteroidal compounds in vitro. Endocrinology 122 1449-1454.

Katzenellenbogen BS 1996 Estrogen receptors: bioactivities and interactions with cell signaling pathways. Biology of Reproduction $\mathbf{5 4}$ 287-293.

Kelly MJ \& Levin ER 2001 Rapid actions of plasma membrane estrogen receptors. Trends in Endocrinology and Metabolism 12 152-156.

Leondires MP, Segars JH \& Walsh BW 1999 The use of antiestrogens in the postmenopausal woman. In Contemporary Endocrinology: Menopause: Endocrinology and Management, pp 179-207. Eds DB Seifer \& EA Kennard. Totowa: Humana Press Inc.

Lieberman ME, Jordan VC, Fritsch M, Santos MA \& Gorski J 1983 Direct and reversible inhibition of estradiol-stimulated prolactin synthesis by antiestrogen in vitro. Journal of Biological Chemistry 258 4734-4740.

McDonnell DP 2003 Mining the complexities of the estrogen signaling pathways for novel therapeutics. Endocrinology 144 4237-4240.

McEwen BS \& Alves SE 1999 Estrogen actions in the central nervous system. Endocrine Reviews 20 279-307.

Mitchner NA, Garlick C \& Ben-Jonathan N 1998 Cellular distribution and gene regulation of estrogen receptors alpha and beta in the rat pituitary gland. Endocrinology 139 3976-3983.
Mitchner NA, Garlick C, Steinmetz RW \& Ben-Jonathan N 1999 Differential regulation and action of estrogen receptor alpha and beta in GH3 cells. Endocrinology 140 2651-2658.

Morishige WK \& Rothchild I 1974 Temporal aspects of the regulation of corpus luteum function by luteinizing hormone, prolactin and placental luteotrophin during the first half of pregnanc in the rat. Endocrinology 95 260-274.

Navarro CE, Saeed SA, Murdock C, Martinez-Fuentes AJ, Aurora KK, Krsmanovic LZ \& Catt KL 2003 Regulation of cyclic adenosine $3^{\prime}, 5^{\prime}$-monophosphate signaling and pulsatile neurosecretion by Gi-coupled plasma membrane estrogen receptors in immortalized gonadotrophin-releasing hormone neurons. Molecular Endocrinology 17 1792-1804.

Neill JD 1972 Sexual differences in the hypothalamic regulation of prolactin secretion. Endocrinology 90 1154-1159.

Neill JD 1988 Prolactin secretion and its control. In The Physiology of Reproduction, pp 1379-1390. Eds E Knobil \& J Neill. New York: Raven Press.

Neill JD, Freeman ME \& Tillson SA 1971 Control of the proestrus surge of prolactin and luteinizing hormone secretion by estrogen in the rat. Endocrinology 89 1448-1453.

Pelletier G, Songyun L, Phaneuf D \& Martel C 2003 Morphological studies of prolactin-secreting cells in estrogen receptor $\alpha$ and estrogen receptor $\beta$ knockout mice. Neuroendocrinology 77 324-333.

Perez-Martin M, Azcoitia I, Trejo JL, Sierra A \& Garcia-Segura LM 2003 An antagonist of estrogen receptors blocks the induction of adult neurogenesis by insulin-like growth factor-I in the dentate gyrus of adult female rat. European Journal of Neuroscience 18 923-930.

Pietras RJ \& Szego CM 1977 Specific binding sites for oestrogen at the outer surfaces of isolated endometrial cells. Nature 265 69-72.

Rothchild I 1981 The regulation of the mammalian corpus luteum. Recent Progress in Hormone Research 37 183-298.

Sánchez-Criado JE, Ochiai K \& Rothchild I 1987 Indomethacin treatment prevents prolactin-induced luteolysis in the rat. Journal of Endocrinology 112 317-322.

Sánchez-Criado JE, Guelmes P, Bellido C, González $M$, Hernández G, Aguilar R, Garrido-Gracia JC, Bello AR \& Alonso R 2002 Tamoxifen but not other selective estrogen receptor modulators antagonizes estrogen actions on luteinizing hormone secretion while inducing gonadotropin-releasing hormone selfpriming in the rat. Neuroendocrinology 76 203-213.

Sánchez-Criado JE, Martín de las Mulas J, Bellido C, Tena-Sempere M, Aguilar R \& Blanco A 2004 Biological role of pituitary estrogen receptors $E R \alpha$ and $E R \beta$ on progesterone receptor expression and action and on gonadotropin and prolactin secretion in the rat. Neuroendocrinology 79 247-258.

Sánchez-Criado JE, Martín de las Mulas J, Bellido C, Aguilar R \& Garrido-Gracia JC 2005 Gonadotrope oestrogen receptor- $\alpha$ and - $\beta$ and progesterone receptor immunoreactivitity after ovariectomy and exposure to oestradiol benzoate, tamoxifen or raloxifen in the rat: correlation with LH secretion. Journal of Endocrinology 184 59-68.

Schmidt BMW, Gerdes D, Feuring M, Falkenstein E, Christ M \& Wehling M 2000 Rapid, nongenomic steroid actions: a new age? Frontiers in Neuroendocrinology 21 57-94.

Smith PK, Krohn RI, Hermanson GT, Mallia AK, Gartner FH, Provenzano MD, Fujimoto EK, Goeke NM, Olson BJ \& Klenk DC 1985 Measurement of protein using bicinchoninic acid. Analytical Biochemistry $15076-85$.

Smith CL \& O'Malley BW 2004 Coregulator function: a key to understanding tissue specificity of selective receptors modulators. Endocrine Reviews 25 45-71.

Snyder G, Naor Z, Fawcett CP \& McCann SM 1981 Action of thyrotropin-releasing hormone on mammotrophs and thyrotrophs. American Journal of Physiology 241 E298-E304.

Spritzer PM, Ribeiro MF, Oliveira MC, Barbosa-Coutinho LM, Silva IS, Dahlem N, Cericatto R \& Pavanato MA 1996 Effects of tamoxifen on serum prolactin levels, pituitary immunoreactive prolactin cells and uterine growth in estradiol-treated ovariectomized rats. Hormone and Metabolism Research 28 171-176. 
Stojilkovic SS, Reinhart J \& Catt KJ 1994 Gonadotropin-releasing hormone receptor: structure and signal transduction pathways. Endocrine Reviews 15 462-499.

Tebar M, Bellido C, Aguilar R \& Sánchez-Criado JE 1994 Inappropriate ovarian feedback in basal gonadotropin secretion in 4-day cyclic rat treated with mefiprestone: role of endogenous estradiol. Journal of Endocrinological Investigation 17 425-430.

Tucker HA 1988 Lactation and its hormonal control. In The Physiology of Reproduction, pp 2235-2263. Eds E Knobil \& J Neill. New York: Raven Press.

Turgeon JL \& Waring DW 1994 Activation of progesterone receptor by the gonadotropin-releasing hormone self-priming signaling pathway. Molecular Endocrinology 8 860-869.

Waring DW \& Turgeon JL 1992 A pathway for luteinizing hormonereleasing hormone self-potentiation: Cross-talk with the progesterone receptor. Endocrinology 130 3275-3282.
Watters JJ, Chun T-Y, Kim Y-N, Bertics PJ \& Gorski J 2000 Estrogen modulation of prolactin gene expression requires an intact mitogen-activated protein kinase signal transduction pathway in cultured rat pituitary cells. Molecular Endocrinology 14 1872-1881.

Yoshioka H, Harada T, Iwabe T, Nagano Y, Taniguchi F, Tanikawa M \& Terakawa N 1999 Menstrual cycle-specific inhibition of the proliferation of endometrial stromal cells by interleukin 6 and its soluble receptor. American Journal of Obstetrics and Gynecology $1801088-1094$.

Received 18 May 2005

First decision 22 July 2005

Revised manuscript received 19 October 2005

Accepted 10 January 2006 